\title{
Middle Palaeolithic technical behaviour: Material import- export and Levallois production at the SU 13 of Oscurusciuto rock shelter, Southern Italy
}

\author{
Giulia Marciani ${ }^{1,2,3}$, Vincenzo Spagnolo ${ }^{3}$, Daniele Aureli ${ }^{3,4}$, \\ Filomena Ranaldo ${ }^{3}$, Paolo Boscato ${ }^{3}$, Annamaria Ronchitelli ${ }^{3}$
}

1. Dipartimento di Studi Umanistici, Sezione di Scienze Preistoriche e Antropologiche, Università degli Studi di Ferrara. C.so Ercole I d'Este 32, 44100 Ferrara, Italy. Email: giulia.marciani@unife.it

2. Department of History, History of Art, Universitat Rovira I Virgili Tarragona. Av. Catalunya, 35, 43002

Tarragona, Spain.

3. Dipartimento di Scienze Fisiche, della Terra e dell’Ambiente, UR Preistoria e Antropologia, Università degli Studi di Siena. Strada Laterina 8, 53100 Siena, Italy. Email: Spagnolo: orpheus.85@hotmail.it;

Aureli: danieleaureli1@gmail.com; Ranaldo: filomenaranaldo@gmail.com; Boscato: paolo.boscato@unisi.it; Ronchitelli: annamaria.ronchitelli@unisi.it

4. UMR 7041 ArScAn équipe AnTET Université Paris Ouest Nanterre La Défense. 21 allée de l’université, F-92023 Nanterre Cedex, 92001 Nanterre, France.

\begin{abstract}
:
The Oscurusciuto rock shelter, located in southern Italy (Puglia), has yielded a long Middle Palaeolithic stratigraphy rich in lithic assemblages, fireplaces and faunal remains, attesting Neanderthal occupation during the MIS 3. This paper is focused on the stratigraphic unit 13, consisting of a sandy compact deposit mixed with pyroclastic sediment above a thick level of tephraUS 14, identified as Mt. Epomeo green tuff (dated $\mathrm{Ar} / \mathrm{Ar} \sim 55 \mathrm{ka}$ ).

Level 13 represents the first stable human occupation after the deposition of tephra. Our goal was to examine the lithic assemblage of this stratigraphic unit by means of an interdisciplinary approach (technology, RMU, refitting program) in order to identify the economic behaviour and technical strategies of Neanderthals occupying the stratigraphic unit 13 of Oscurusciuto.

The technical strategies applied indicate fragmentation of the reduction processes, as well as probable events of importation and exportation of objects. The lithic material were introduced at different stages of manufacturing. Pieces were introduced in the form of rough objects (pebbles), as well as semi-finished items, and as finished tools. This fragmentation of the chaîne opératoire also demonstrate the palimpsest nature of the level which is made up of different events happening one after another.

The main concept of debitage was Levallois, generally realized on local jasper and siliceous limestone pebbles or cortical flakes. Jasper and siliceous limestone flakes, backed flakes and convergent flakes were the technological objectives of the debitage. A marginal volumetric debitage aimed at producing bladelets was also attested.
\end{abstract}

Keywords: Middle Palaeolithic; Neanderthals; technical behaviour; lithic; southern Italy

Published by the School of History, Classics and Archaeology, University of Edinburgh ISSN: 2055-0472. URL: http://journals.ed.ac.uk/lithicstudies/

This work is licensed under a Creative Commons Attribution 2.5 UK: Scotland License. 


\section{Introduction and background}

The fragmentation of the reduction sequences is a behaviour already attested in other Middle Palaeolithic sites (Bataille 2006; Bourguignon et al. 2004; Moncel et al. 2014; Neruda 2010; 2012; Romagnoli 2015; Spagnolo et al.2016; Turq et al. 2013; Uthmeier 2006; Vaquero 2008; Vaquero et al. 2001; 2012a; 2012b). It proves the capacity of Neanderthals for adopting flexible strategies of occupation and use of the land and it is also an indicator of their mobile nature. The different stages of acquisition, transport, knapping and abandonment of lithic implements, identified individually or together in the same archaeological record, suggest that the strategies related to the management of lithic materials are different and independent from each other (Fernández-Laso et al. 2011; Turq et al. 2013).

It is clear that the lithic material imported to a site was introduced in various ways: as raw blocks, as half-finished objects, or as already manufactured tools. The export of tools and their abandonment on site as waste material has also been documented. The complexity related to the mobility of lithic objects is directly linked to the spatial, temporal and social domains (Turq et al. 2013). This means that even though lithic objects appear together in the same archaeological record they are associated with various geographical places. They could be introduced in a site during different episodes temporally far from each other. Moreover they could also indicate some social process of the groups using the region.

Another technical behaviour, which is often simultaneously present with fragmented reduction sequences, is the recycling of ancient waste resulting from production and reusing it as support for knapping and obtaining new tools. This behaviour, especially regarding its recognition, is very debated in archaeological literature (Romagnoli 2015; Vaquero 2011; Vaquero et al. 2012; 2015;). In terms of land use, the behaviour of recycling could be related to the scarcity of good raw material in the region and thus it substantiates the need to reuse the same tools rearranged many times for different tasks and necessities (Amick 2007; Close 1996; Dibble \& Rolland 1992; Hiscock 2009; Kelly 1988). Alternatively, it could be a specific strategy, which relates to occasional and expedient behaviour and unplanned necessity (Vaquero et al. 2012). This is a characteristic usually encountered in populations with high mobility in the territory (Kuhn 2014; Romagnoli 2012; Romagnoli et al. 2015).

Although the data are still partial and there are few studies with techno-economic approach, Middle Palaeolithic populations of southern Italy (we mainly consider the region of Puglia in this paper) stand out for their high adaptability and flexibility of the knapping scheme and for their mobility in the territory (Carmignani 2010; 2011; Marciani 2013; Romagnoli 2012; 2015; Romagnoli et al. 2015; Spinapolice 2012;).

In this paper, we aim to examine the Oscurusciuto rock shelter, which is located in the ravine of Ginosa - Taranto in the region of Puglia, southern Italy. The site presents several anthropic layers with a lithic production of a predominantly unipolar Levallois method (Boscato et al. 2011; Lazzeri 2005; Marciani 2013; Ranaldo 2005; Ronchitelli et al. 2011; Spagnolo et al. 2016; Villa et al. 2009).

There are several current studies on this site, and the principal aim of our research is to provide an integrate and complete data-set concerning the Neanderthal behaviour on site: their strategies of production, trade and use of lithic tools; their management of space as well as their subsistence strategies, all related to environment.

Specifically, the main goal of this paper is to understand the technical behaviour of Neanderthals in the Stratigraphic Unit 13 (SU 13). Consequently the study integrates various types of lithic studies, among others the technological approach, to obtain information about the techniques and methods of knapping and the manufacturing of target flakes. The Raw Material Units (RMU) method, used to identify individual events of raw material introduction into the site, has permitted us to supply more detailed interpretations of individual choices 
regarding the management of the stone material involved. Moreover refittings and conjoints are crucial to fully understand the technological behaviour in question, and also to measure the reliability of each RMU (Marciani 2013; Spagnolo 2013; Spagnolo et al. 2016).

\subsection{The site}

Research, investigation and excavation at the Oscurusciuto rock shelter have been carried out since 1998 until the present day by the U.R. Preistoria e Antropologia under the Dipartimento di Scienze Fisiche, della Terra e dell’Ambiente - University of Siena, Italy.

The Oscurusciuto rock shelter opens into the Pleistocene calcarenite, at about 15 meters from the current bottom of the ravine, standing at an elevation of $235 \mathrm{~m}$ asl (Figure 1). The Ionic coast line is currently at about $20 \mathrm{~km}$ from the site.

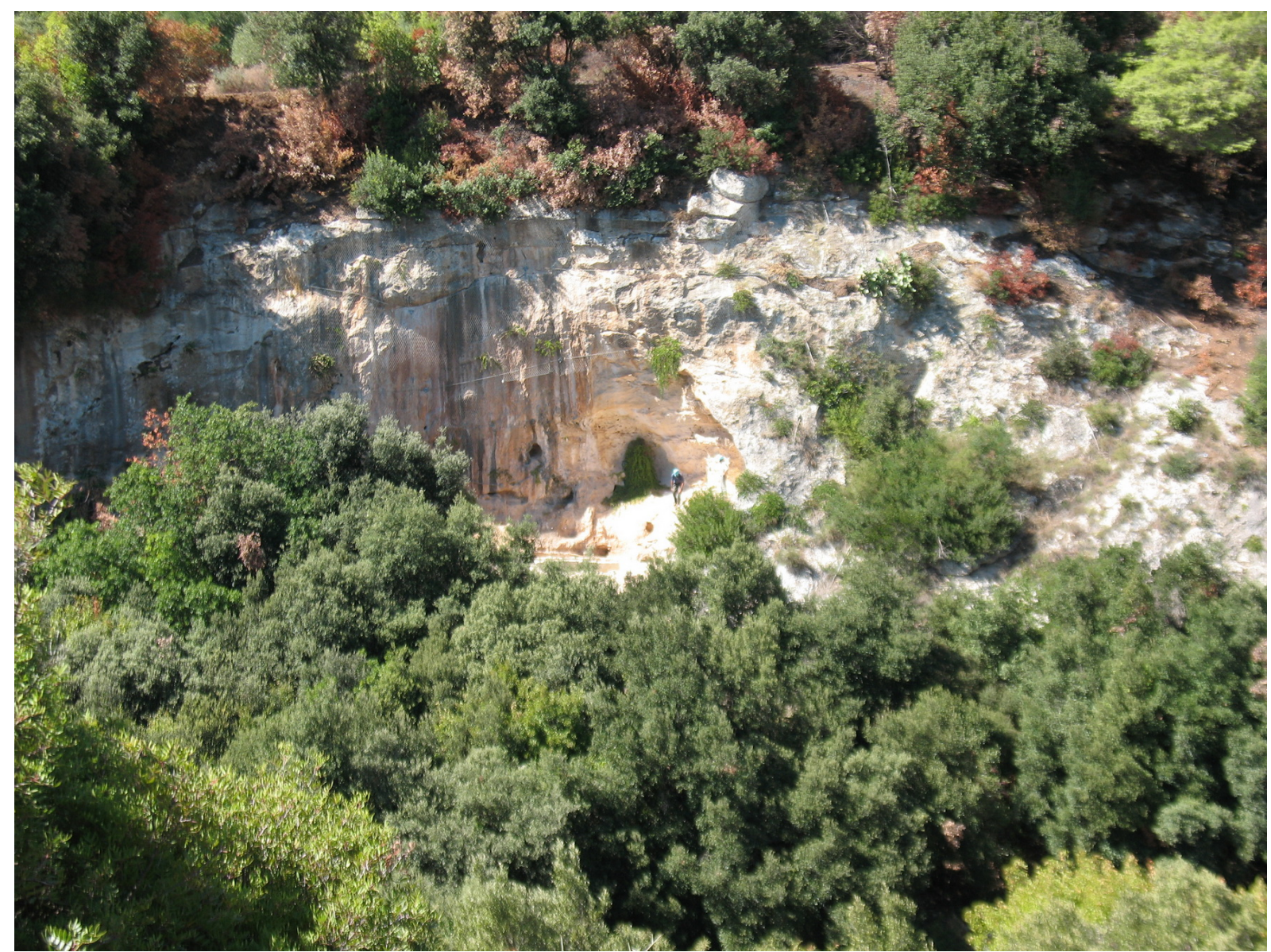

Figure 1.The Oscurusciuto rockshelter in the northern side of the ravine of Ginosa. (Photo by P. Boscato.)

The location of the site plays a primary role, as this rock shelter is located in the central part of Puglia, which represents a crossroads for different areas of southern Italy: Salento (south), Murge and Gargano (north), plus the area of the Gulf of Taranto and Basilicata (Figure 2a). This region also seems to be crucial for the first diffusion of the Anatomically Modern Human in Europe (Moroni et al. 2013). 


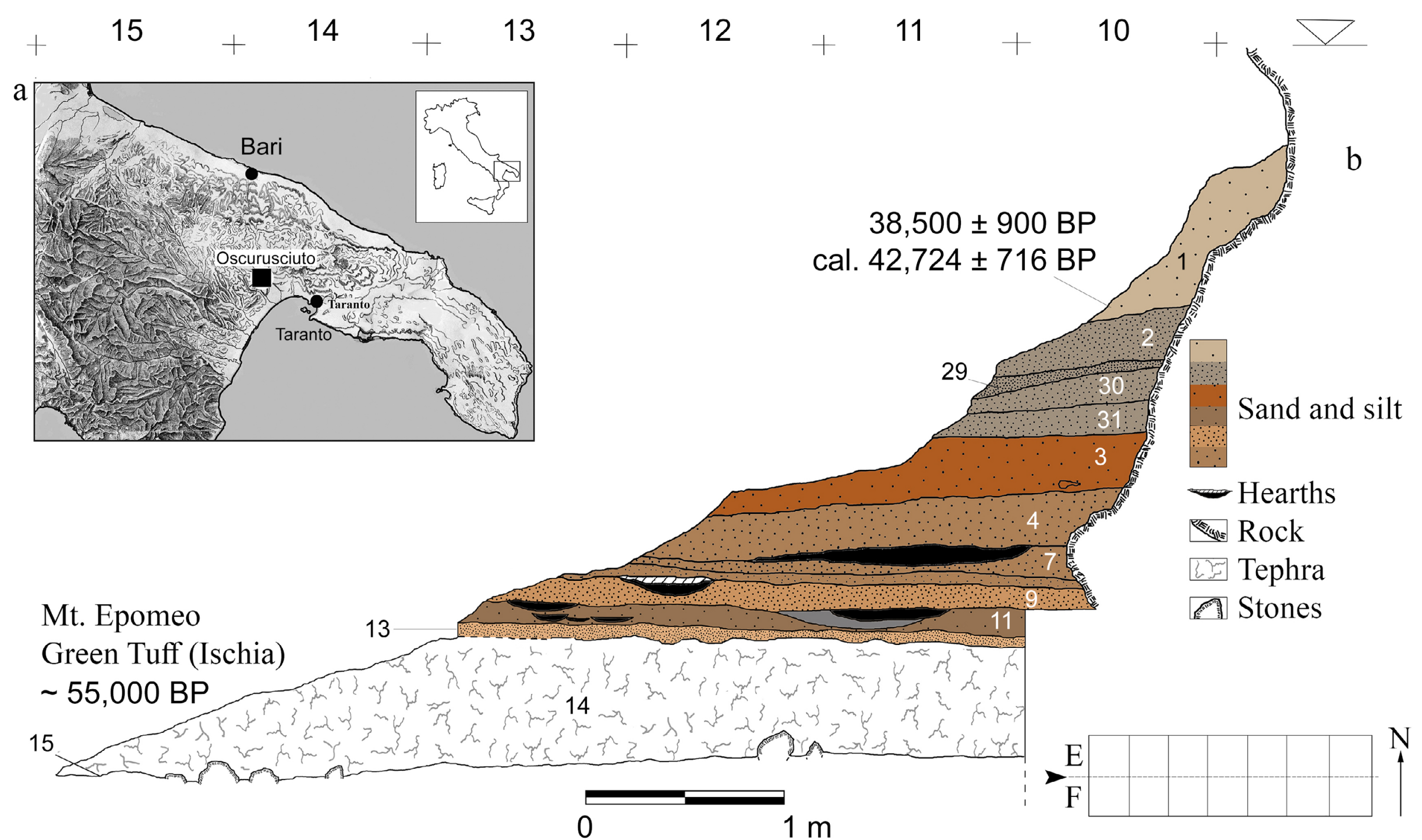

Figure 2. Localization (a) and stratigraphic sequence (so far excavated) of the Oscurusciuto rock shelter (b). (Relief map by P. Boscato; drawing by A. Ronchitelli). 
At some point the original shelter vault collapsed, leaving today only a little coverage above the site. The deposit consists of approximately $60 \mathrm{sq} \mathrm{m}$ at the base, reaching a depth of $6 \mathrm{~m}$ in its central part so far excavated. The stratigraphic sequence is made up of several horizontal levels (Figure 2b), which refer to the final stage of Middle Palaeolithic: the date of the lower part of SU 1 is $38.500 \pm 900$ BP - AMS, Beta 181165; cal. $42.724 \pm 716$ BP (for calibration see OxCal v4.2.4 Ramsey \& Lee 2013). The tephra deposit SU 14 was attributed to the green tuff of Mount Epomeo Ischia, identified in the stratigraphic series of Monticchio, dated to 55 ky BP (Allen et al. 2000).

The data corresponding to the first part of MIS 3 indicate a period characterized by rather cold and dry climatic fluctuations. The faunal remains from the lower part of the analysed deposit (SU 15 to SU 4), exclusively attributed to human activities, are characterized by high frequencies of Bos primigenius, in association with Cervus elaphus, Dama dama, Capreolus capreolus, Equus ferus and by rare appearances of Capra ibex and Rupicapra. Sporadic remains of carnivores, Panthera leo and Canis lupus, have also been found. In the upper units the amount of deer and horse is more frequent (Boscato \& Crezzini 2012; Spagnolo et al. 2016). The faunal association dominated by these taxa indicate that the environment was forest steppe with limited wooden coverage areas.

Regarding the lithic industry of the site, the units so far excavated (SU 15 to SU 1) are characterized by a great predominance of the Levallois concept. The lithic material from the upper levels SU 1 and SU 4 was mainly produced employing the recurrent unipolar Levallois method, the bipolar modality being less represented. In the last phases of debitage, the production could change from unipolar to centripetal modality. The principal aim of production was to realise elongated flakes sometimes retouched. Among those, scrapers are dominant, followed by denticulates and points. Also represented a volumetric orthogonal method (Boscato et al. 2011). The lithic production of the SU 8 can be assimilated to the upper layer, consisting predominantly of Levallois production, with reduced presence of volumetric debitage and insignificant discoid production. During the last phases of debitage, the Levallois cores were rearranged in a centripetal or preferential production, aimed at producing flakes (Ranaldo 2005; Ronchitelli et al. 2011; Villa et al. 2009).

The middle and lower part of the investigated stratigraphic sequence yielded many occurrences of combustion structures. In the SU 13, SU 11 and SU 9 the hearths have two dimensional typologies: small (with diameters of about $20 \mathrm{~cm}$ ) and large (around $50 \mathrm{~cm}$ in diameter). In these stratigraphic units most hearths are located in a belt, separated from the rock shelter wall. In the SU 7 a big hearth (2 m wide) is located in the N-W corner of the shelter. Data suggest that this rock shelter was repeatedly used by Neanderthals during that period; especially in the upper layer there is a significantly different evidence of management of space, with a dissimilar disposition and type of hearths (Boscato \& Ronchitelli 2008). SU 13 represents the first stable occupation after the deposition of tephra, SU 14 attests the deposition of tephra with a sporadic and rapid occupation at the end of its accumulation, and SU 15 documents the phases of abandonment of a living floor with evidence of structures.

The SU 13 consists of a compact sediment of sand and small amounts of tephra (that upward progressively rarefy) with small pieces of calcarenite, resulting from the collapse of the shelter walls. This level is a short palimpsest and it has not been excavated in its full extension because partly destroyed by erosion. Two parts were left untouched as a stratigraphic balk, so the layer was excavated for the extension of 11 square meters (Figure 3). The level is characterized by the presence of 10 hearths and quite a lot of faunal remains; however, only six elements were identified, due to high fracture grade (1 = Equus ferus and 5 = Bos primigenius) (Spagnolo et al. 2016). 


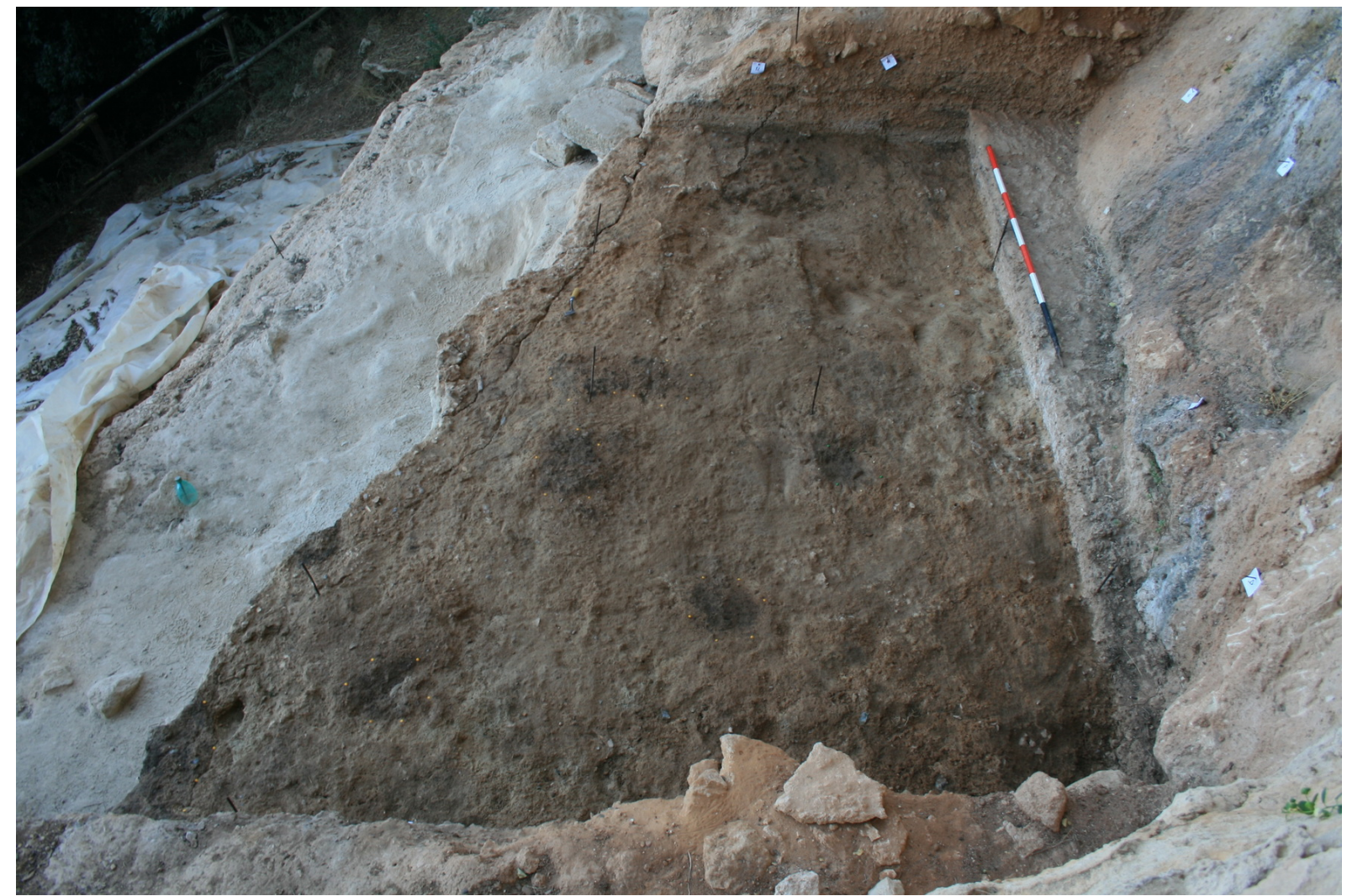

Figure 3. The top of SU 13. (Photo by P. Boscato.)

\section{Material and Methods}

The lithic assemblage from SU 13 of the Oscurusciuto rock shelter was analysed using technological analytic methods in order to define the techno-economic processes and technological sequences (Boëda 1982; 1993; 1994;, 2013; Forestier 1993; Geneste 1991; Inizan et al. 1999; Leroi Gourhan 1943; Revillion \& Tuffreau 1994).

As a first step, the lithic material was divided into five dimensional classes (DC) (first: 1$50 \mathrm{~mm}^{2}$, second: $51-100 \mathrm{~mm}^{2}$, third: $101-150 \mathrm{~mm}^{2}$, fourth: $151-200 \mathrm{~mm}^{2}$, fifth: $>200 \mathrm{~mm}^{2}$ ) on the basis of the area covered by each specimen size. These size classes are necessary for the spatial analysis, in order to identify eventual activity areas and to verify if there was sorting processes of the material due to water flow. The items larger than the second DC were also measured according to their technological axes. Subsequently, all the material was sorted according to the nature and granulometry of the raw material (chert, jasper, siliceous limestone, limestone and quartz sandstone).

Finally, all the technological characteristics of each piece were considered and registered in an Access Database. We took into consideration the technological classes: flakes, cores, pebbles, micro flakes (integral flakes of the first and second DC), debris (fragmented pieces of the first and second DC) and indeterminate fragments (fragmented or altered pieces of the third, fourth and fifth DC). For the flake class we individuated the concept and method of debitage. Then considering the role of each flake (F) during the debitage we were able to recognize the technological categories: predetermining $\mathrm{F}$, predetermined $\mathrm{F}$ and indeterminate F. The category of predetermining $F$ includes: completely cortical $F(100 \%$ of cortex coverage), semi-cortical F (between $99 \%$ and $50 \%$ of cortex coverage) and management $\mathrm{F}$ (all the flakes that are involved in regulating the convexities and angles of a core with less than $50 \%$ of cortex coverage). The category of predetermined $\mathrm{F}$ encompasses the target $\mathrm{F}$, which are the predetermined objective of the debitage (with or without cortex coverage). Finally the 
indeterminable $\mathrm{F}$ are all the flakes which are too altered or too fragmented to determine their proper role in the knapping activity.

As far as the flakes were concerned, we considered the amount and localization of cortex; the presence of alteration (chemical, post depositional or due to fire) and retouch or traces. We also considered their morphological aspects (morphology, symmetry and section shape); the number and orientation of dorsal scars; the type of butt and bulb; and finally the position of impact point.

A more detailed study on the core was also performed. For this analysis we took into consideration the kind and morphology of support; the volumetric conception of the exploitation; the hierarchy of surfaces; the type, location and way of preparation of the striking platform; the number and direction of the negatives on the surface of debitage; and the possible reason for the abandonment of the core itself.

This technological study was implemented by Raw Material Units analysis (RMU) (also known as MANA: Minimum Analytical Nodule Analysis in American literature), in addition to an intensive program of refits based on the material, in order to identify the technical events from a spatio-temporal perspective (RMU: Chacón et al. 2015;Cziesla 1990; LópezOrtega et al. 2011; 2015; Machado et al. 2013; 2015; Marciani 2013; Roebroeks 1988; Romagnoli 2012; Schurmans 2007; Spagnolo 2013; Spagnolo et al. 2016; Uthmeier 2006; Vallverdù et al. 2010; Vaquero 2008; Vaquero et al. 2001; 2012a; 2012b; 2015; MANA: Bruce 2001; Byrnes 2009; Cooper \& Melzer 2009; Douglass 2010; Hall 2004; Hall \& Larson 2004; Hurst et al. 2010; Knell 2012; Larson 1994; Larson \& Ingbar 1992; Larson \& Finley 2004; Larson \& Kornfeld 1997; Miller 2016; Scerri et al. 2016; White 2012; Yoshikawa 2010).

To perform the RMU analysis lithic artefacts were sorted on the base of their macroscopic traits such as cortex colour and thickness, texture, colour, inclusions and opacity. Burnt, patinated or altered pieces and tiny specimens were excluded from this analysis.

A RMU can be defined as the material outcome of a knapping event, or as a series of knapping events carried out from a specific nodule (Moncel et al. 2014; Roebroeks 1988; Vaquero 2008). It permits dissecting the lithic complex into its smallest units, which are each of the single raw nodules introduced into the site. These data can be useful for two kinds of interpretation: from a spatial-temporal point of view, or from a technological perspective. The role of the RMU in a spatial context and its temporal significance have already been presented in a recent paper (Spagnolo et al.2016), hence we will focus on the technological value of RMU analysis and in particular on its functionality in the identification of the fragmentation of reduction sequences.

This methodology has previously been applied to other Middle Palaeolithic contexts (Chacón et al. 2015; Machado et al. 2011; 2013; 2015; Marciani 2013; Moncel et al. 2014; Spagnolo 2013; Spagnolo et al. 2016; Turq et al. 2013; Vaquero et al. 2012a; 2012b; 2015).

\section{Results}

\subsection{Lithic production}

In this SU, 7504 lithic artefacts were found. Their preservation condition is very good and their edges are fresh, though the artefacts surfaces show a slight patina caused by chemical alteration. Due to the presence of hearths, some artefacts show various degrees of alteration by fire: 212 elements have been identified with clear burn traces.

The raw material imported into the Oscurusciuto site is characterized by great macroscopic variability. As in all the upper stratigraphic units, the dominant raw materials are jasper and siliceous limestone in their fine granulometry, found in the form of pebbles, which 
can still be found on the sea-terraces and river deposits around the site (nowadays almost between few tens of meters and $1 \mathrm{~km}$ far from the site) (Table 1).

Table 1. Lithological classes. 4025 pieces, because of their tiny dimension (mostly micro flakes and debris of the first and second DC), are excluded from the table.

\begin{tabular}{lcc} 
Raw material & Quantity & \% \\
Fine and medium jasper & 1287 & 37.0 \\
Fine chert & 261 & 7.5 \\
Medium chert & 344 & 9.9 \\
Quartz sandstone & 161 & 4.6 \\
Limestone & 70 & 2.0 \\
Siliceous limestone & 1356 & 39.0 \\
Total & $\mathbf{3 4 7 9}$ & $\mathbf{1 0 0}$ \\
\hline
\end{tabular}

The pebbles imported into the site show a standardized selection of volume (oblongs, oval pebbles), which plays an important role in the choice of the debitage technique. Notably, this morphology is particularly suited to the Levallois concept mainly used at the site. In the conglomerates still visible today nearby the site, there are pebbles with various dimension and shapes. From rather small (between 2 and $3 \mathrm{~cm}$ ) with angular shape to quite large (more than $10 \mathrm{~cm}$ ) with oval and globular shape. As the research stand now it is not possible to give an estimation of the dimension of the pebbles used by prehistoric people at the Oscurusciuto, but what we know is that completely exploited cores have dimension that range between 4 and 5 $\mathrm{cm}$. The few pebbles imported as raw material measure between 3 and $4 \mathrm{~cm}$ and the only core abandoned at the beginning of its debitage measure $7 \times 5 \mathrm{~cm}$.

There is evidence of knapping activity at the site, as revealed by the great presence of micro-flakes (2212) and debris (3446) (debitage waste). This is also highlighted by the spatial analysis that suggests the presence of drop zones (Spagnolo et al. 2016). The technological categories of the lithic collection (Table 2) show that all the phases of the chaîne opératoire are represented in compatible proportions to the knapping activity. Completely-cortical flakes (20) and semi-cortical flakes (266) attest to the very early stages of production, i.e. the opening of the pebble. The management (667), target (344) and retouched (30) flakes indicate the production phase. Finally the cores represent the abandonment. This data may lead to a misinterpretation of the lithic complex because it might make us conclude that several completed reduction sequences had been carried out at the site. This is not the case, in fact thanks to the combined technological studies and the analysis of the RMUs it is possible to point to a more complex and fragmented picture. The lithic collection consists of an addition of various events of manufacture, management, importation and exportation of the lithic material at different stages of production, leading to the conclusion that the archaeological record under investigation is a palimpsest of different actions or events (Hallos 2005; LópezOrtega et al. 2015; Machado et al. 2013; 2015; Rios-Garaizar et al. 2015; Spagnolo et al. 2016; Vallverdù et al. 2005; 2010; Vaquero 2008; Vaquero et al. 2001; 2012b).

Just two kinds of debitage were utilized at the level 13: the Levallois concept (documented on the bases of 575 flakes and 18 cores) and the volumetric reduction sequence (15 flakes and 6 cores). All the other flakes (e.g., cortical flakes, indeterminable flakes) and cores do not show enough technical parameters to be able to identify other mode of debitage.

In total, 33 cores have been found. They represent $0,4 \%$ of the analysed produce (Table 3).

The group of indeterminable cores is made up of pieces that are in the early stages of exploitation or appear too fragmented. Those pieces do not have the technical characteristics needed to define their concept of debitage. Eighteen cores refer to the Levallois concept. 
Some of them, which appear too exploited, do not allow the definition of a method of production (indeterminate Levallois). Whereas the others have been equally divided into unipolar or convergent Levallois.

Table 2. Technological composition.

\begin{tabular}{lll} 
Technological category & Quantity & \% \\
Pebbles & 9 & 0,1 \\
Completely-cortical flakes & 20 & 0,3 \\
Semi-cortical flakes & 263 & 3,5 \\
Management flakes & 667 & 8,9 \\
Micro-flakes & 2212 & 29,5 \\
Indeterminate flakes & 203 & 2,7 \\
Target flakes & 344 & 4,6 \\
Retouched tools & 30 & 0,4 \\
Cores & 33 & 0,4 \\
Indeterminable pieces & 277 & 3,7 \\
Debris & 3446 & 45,9 \\
Total & $\mathbf{7 5 0 4}$ & $\mathbf{1 0 0}$ \\
\hline
\end{tabular}

Table 3. Core concepts.

\begin{tabular}{llc} 
Concept & & Quantity \\
Levallois & Unipolar & 5 \\
Levallois & Convergent & 6 \\
Levallois & Indeterminate & 7 \\
Volumetric & & 6 \\
Indeterminable & & 9 \\
Total & & $\mathbf{3 3}$ \\
\hline
\end{tabular}

\subsubsection{Levallois reduction sequence}

The first phase attested is the selection of supports, whose morphology and convexity enable the initialization of the core by means of the Levallois concept without a proper phase of preparation of the core. After the striking platform opening, follows the cortex removal of the surface of debitage by means of two or three unipolar extractions. Some instances of refitting attest that these unipolar semi-cortical flakes are already the first generation of target objects. Moreover, they also possess the technical characteristic to install the convexity and the guide ribs for the next generation of target flakes.

Subsequently, the presence of flakes involved in the management of lateral and distal convexities have been attested, in preparation of a striking platform and in order to generally manage the cores (management flakes; indeterminate flakes, micro-flakes). These flakes are meant to create the technical characteristic needed to allow the extraction of other predetermined items. The objects that Neanderthals sought to produce here were flakes, backed flakes and convergent flakes. Some of these flakes, besides being target products (predetermined), also have the function of predetermining and re-establishing the right convexity for successive removals (Figure 4). 

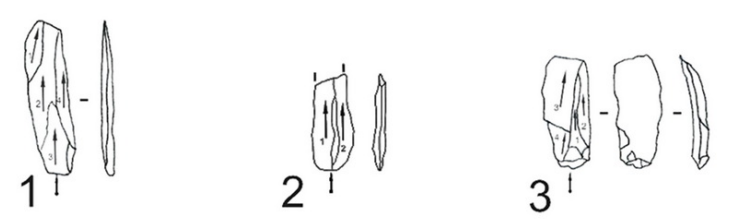

$4 \mathrm{~cm}$
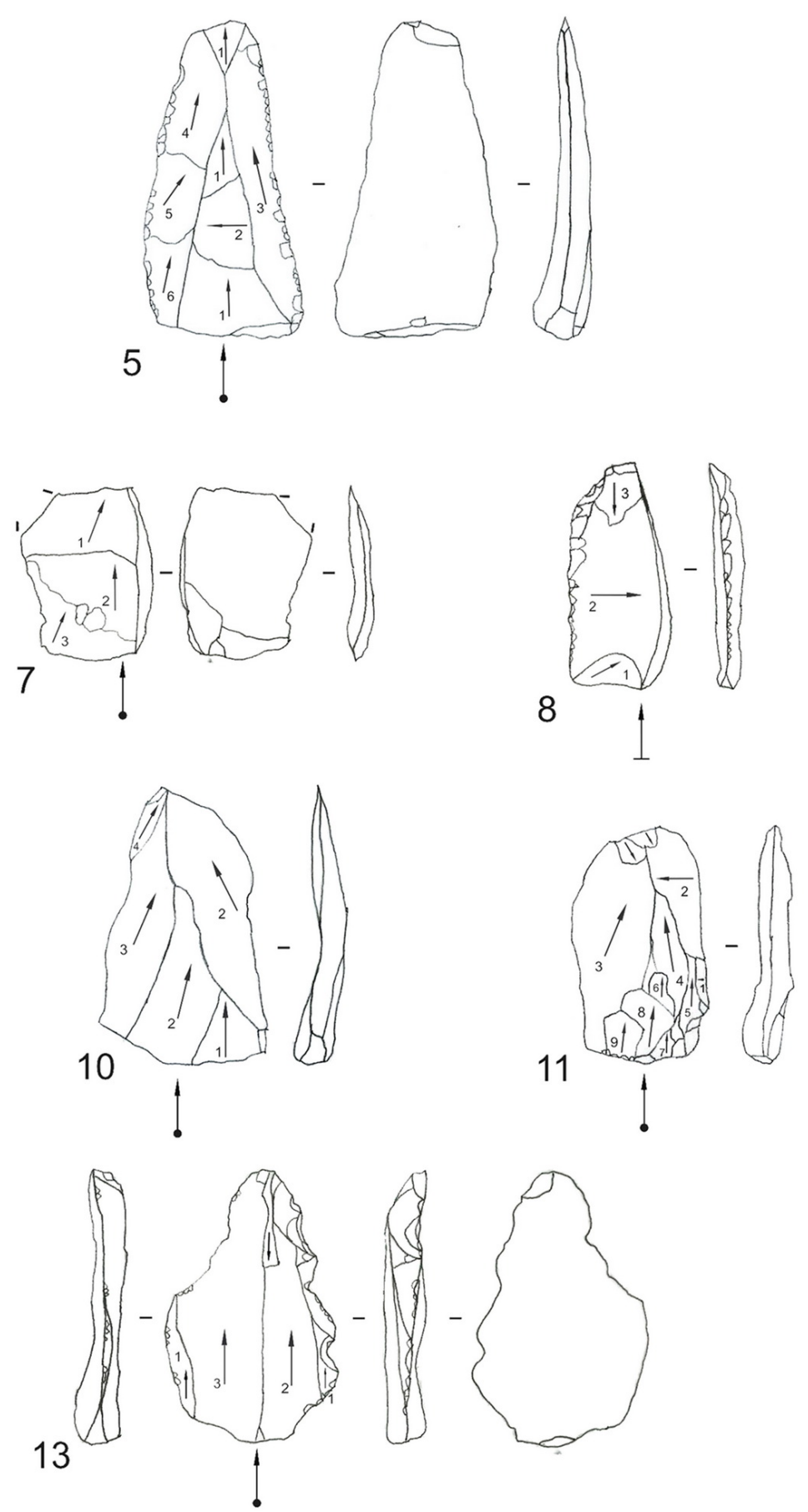

Figure 4. Drawing of target flakes and retouched tools. 1, 2, 3: bladelets, target objective of volumetric production; 4: retouched tool: denticulate point; 5, 6, 10: convergent flakes target objective of Levallois production; 7, 8, 14: backed flakes, target objective of Levallois production; 9,11,12: flakes, target objective of Levallois production; 13: retouched tool: denticulate scraper. 
The most used blanks for the Levallois debitage are pebbles and few completely cortical flakes. Thanks to a diacritical analysis, it is possible to determine that the cores, although incidentally, were used until the exhaustion of the reserve of raw material: they were finally abandoned only after repeated rescue attempts. In many cases after a hinged incident there are a lot of other strike performed in order to remove the incident and carry on with the knapping activity (Buonsanto 2012, Buonsanto \& Peretto 2012). This behaviour is attested on the base of 7 cores. Only one core was abandoned with no further rescue attempt, due to an error in the early stages of exploitation.

In the unipolar Levallois process, it is common to have one or more partial striking platforms, one of which is used for the extraction of target products, i.e. flakes, backed flakes and convergent flakes. The other striking platform, usually on the left, is utilized for the management of distal and lateral convexity by removing little orthogonal flakes. On the right, the craftsman knapped in order to obtain debordant cortical flakes, which are both predetermined and predetermining, playing indeed a double role: they manage the convexities but they are also target objectives. On the contrary, in the convergent Levallois process, the plan of percussion is a large partial one, and both the management and the production of flakes take place from the same striking platform. That means that both researched flake and management flake come from the same striking platform (Figure 5). As for the unipolar modality the target products of the convergent Levallois production are convergent flakes and backed flakes. The Levallois production at this level of Oscurusciuto is recurrent, for this reason, just on the base of the diacritical study of the scar on flakes, is not always possible to recognize a clear break between the two modalities (unipolar and convergent). Leading to the conclusion that convergent and baked flakes could be the aim of both modalities.

The transformation process is evident in the retouched items. Only 30 pieces proved to have been retouched and this is a tiny number compared to the amount of pieces from the production as a whole. Therefore, it is clear that at this point Neanderthals did not feel the need to retouch the supports, but used the sharp edges directly obtained by debitage. The technological category mostly thought to have been selected for retouching is the flake, with a total number of 15 tools, 5 tools made on convergent flakes (Table 4).

Consequently, it can be stated that the majority of the retouched pieces have been made on target flakes (Figure 4). However, there are also a few retouched tools made for managing flakes, such as cortical and generic flakes. The most common retouched tool is the sidescraper with 13 items (Table 4), the majority of which were obtained from the category of flakes and backed flakes.

\subsubsection{Volumetric reduction sequences}

Compared to the Levallois concept, the volumetric exploitation is merely marginal (Table 3), indeed only 10 bladelets, 5 bladelets management flakes and 6 cores attest to the presence of this production process. The volumetric debitage consists of short reduction sequences made exclusively on flakes or fragments. These blanks were chosen because of their technical characteristics, which permit the production of bladelets without a real preparation of the core. The knappers took advantage of the ribs, angles and convexities partially already present on these pieces to initialize the core. What is interesting is that usually the volumetric cores are abandoned before the phase of real production.

Thanks to the diacritical analysis of those cores it was possible to ascertain that they were aimed at producing bladelets (Figure 4). We can summarize the technical parameters of bladelets as follows: pseudo rectangular and symmetrical morphology support, presence of central guide rib and usually two unipolar detachments for side management (Figure 4). These bladelets were not retouched. 

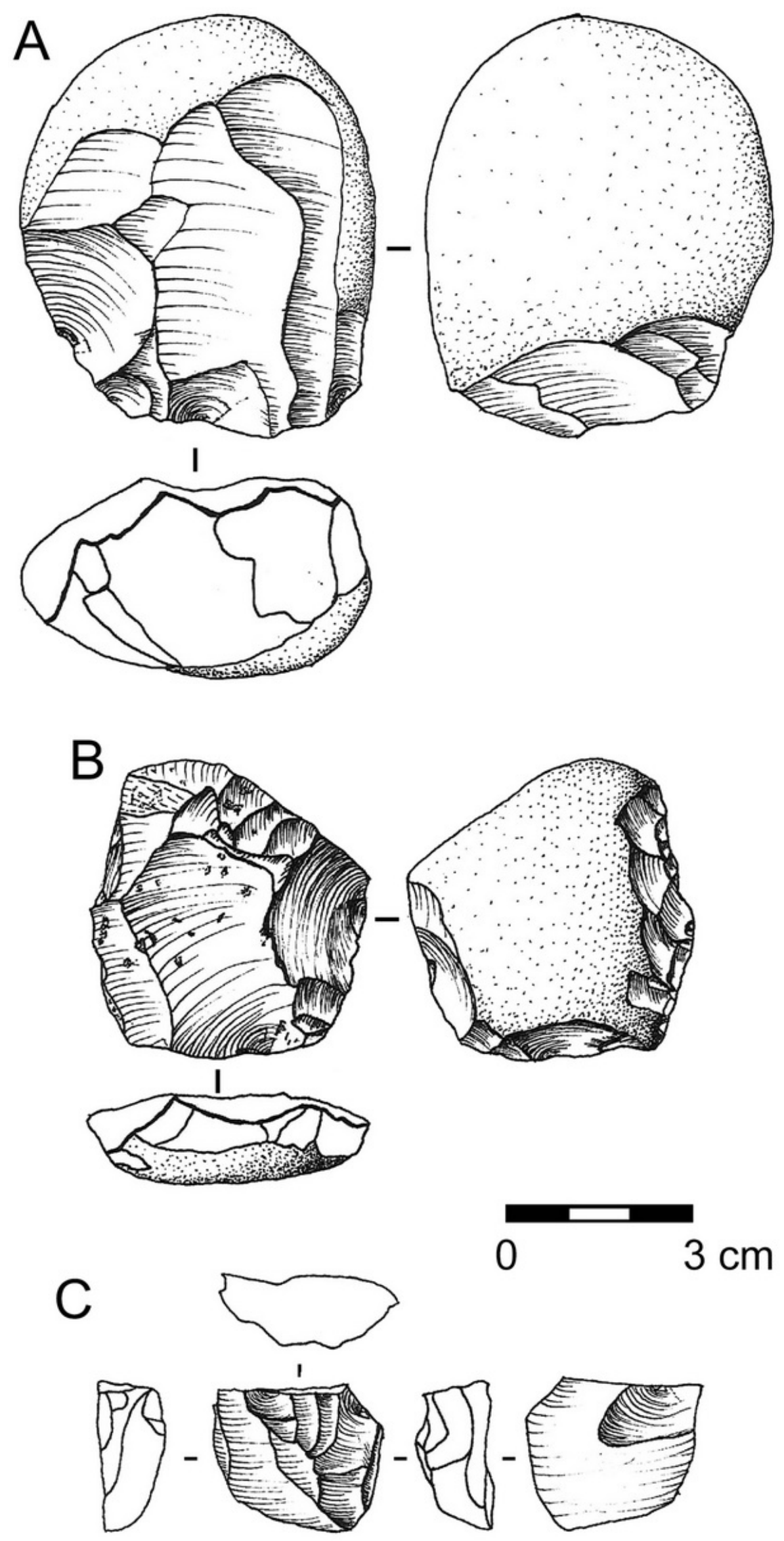

Figure 5. Drawing of cores. A: unipolar Levallois; B: convergent Levallois; C: Volumetric. 
Table 4. Retouched tools and technological category.

\begin{tabular}{|c|c|c|c|c|c|c|c|}
\hline $\begin{array}{l}\text { Technological } \\
\text { category }\end{array}$ & Notch & $\begin{array}{l}\text { Denticulate } \\
\text { scraper }\end{array}$ & $\begin{array}{l}\text { Lateral } \\
\text { scraper }\end{array}$ & $\begin{array}{c}\text { Denticulate } \\
\text { point }\end{array}$ & $\begin{array}{l}\text { End } \\
\text { scraper }\end{array}$ & $\begin{array}{l}\text { Retouched } \\
\text { fragment }\end{array}$ & Quantity \\
\hline Cortical F & 1 & & 2 & & & & 3 \\
\hline Management F & 1 & 1 & & & & & 2 \\
\hline Flakes & 1 & 3 & 6 & 1 & 2 & 2 & 15 \\
\hline Convergent $F$ & & & 2 & 1 & & 2 & 5 \\
\hline Backed F & & & 3 & & & & 3 \\
\hline Indeterminable & & & & & & 2 & 2 \\
\hline Total & 3 & 4 & 13 & 2 & 2 & 6 & 30 \\
\hline
\end{tabular}

\subsection{Target objectives: Flakes, backed flakes, convergent flakes, bladelets}

The Levallois reduction sequence is an integrate concept that allows production of a great quantity of predetermined products with specific characteristics and dimensions (Boëda 2013). In this section we would like to evaluate the recurrent features of these target objects in order to identify what technical characteristics were sought for each type.

Generally, the target object has quite constant characteristics, which are summarized in Table 5. Notably, there are rectangular symmetrical bladelets; oval and trapezoidal, often symmetrical flakes; oval backed flakes; and triangular convergent, even asymmetrical, flakes. The sections are generally triangular, but in some cases trapezoidal for flakes and convergent flakes, and in shape of rectangular trapeze for backed flakes. The cortex is absent or slightly invasive for all categories, except for the backed flakes, $80 \%$ of which have a dorsal cortex. This particular feature of the backed flakes may indicate that these items were created to present a sharp side opposite a backed cortical side, which was very useful as a prehensile part. All types of flakes have rather unipolar negatives, except for the convergent one, in which the negatives are convergent. The number of negatives fluctuates between 2 and 4 .

Table 5. Target products main characteristic

\begin{tabular}{|c|c|c|c|c|}
\hline Characteristic & Bladelets & Flake & Backed flakes & Convergent flakes \\
\hline Total number & 26 & 200 & 37 & 88 \\
\hline Morphology & rectangular & $\begin{array}{l}\text { oval; } \\
\text { trapezoidal }\end{array}$ & oval & triangular \\
\hline Symmetric & $92 \%$ & $64 \%$ & $59 \%$ & $44 \%$ \\
\hline Section shape & triangular & $\begin{array}{l}\text { triangular; } \\
\text { trapezoidal }\end{array}$ & $\begin{array}{l}\text { triangle; rectangular } \\
\text { trapeze }\end{array}$ & $\begin{array}{l}\text { triangular; } \\
\text { trapezoidal }\end{array}$ \\
\hline $\begin{array}{l}\text { Cortex until half of } \\
\text { the surface }\end{array}$ & $4 \%$ & $23 \%$ & $81 \%$ & $7 \%$ \\
\hline Cortex localization & distal & lateral & dorsal & lateral \\
\hline Scar directions & unipolar & unipolar & unipolar & convergent \\
\hline Scar number & $2 ; 3$ & $3 ; 2 ; 4$ & $2 ; 3 ; 4$ & $3 ; 4 ; 2$ \\
\hline Butt & flat; point-form & facetted; flat & facetted; flat & $\begin{array}{l}\text { facetted; chapeau } \\
\text { de gendarme; flat }\end{array}$ \\
\hline $\begin{array}{l}\text { Impact point } \\
\text { Bulb }\end{array}$ & $\begin{array}{l}\text { central } \\
\text { not prominent }\end{array}$ & $\begin{array}{l}\text { central } \\
\text { prominent }\end{array}$ & $\begin{array}{l}\text { lateral } \\
\text { not prominent }\end{array}$ & $\begin{array}{l}\text { central } \\
\text { prominent }\end{array}$ \\
\hline
\end{tabular}

The butts are flat and point-shaped for bladelets, faceted and flat for the other types of flakes, and faceted chapeau de gendarme for the convergent flakes. The impact points are central, with the exception of the backed flakes which have lateral impact points. The flakes and convergent flakes have prominent bulbs, while bladelets and backed flakes have no prominent bulb. 
From the dimensional point of view the Levallois products show very variable dimensions, ranging from rather small items $(1.5 \mathrm{~cm}$ in length) to quite large ones $(7.5 \mathrm{~cm}$ in length). This dimensional variability is due to the recurrent nature of the Levallois process, which enables a continuous production of flakes without a restructuration of the core, producing the same type of target flakes in a variety of dimensions. This leads to a progressive reduction of the cores, and thus of their products. On the other hand, the items resulting from volumetric production show a certain dimensional consistency: the ratio between length and width is almost the same for all pieces. This might be interpreted as a wish to produce bladelets of only one size, whereas the former production method testifies to the need of producing items of different sizes.

The graph (Figure 6) shows the distribution of values of the elongation index of the four categories of target flakes identified at the SU 13. Flakes and convergent flakes have elongation index values lower and more concentrated than bladelets and backed flakes, which are longer but with a higher variation of elongation index.

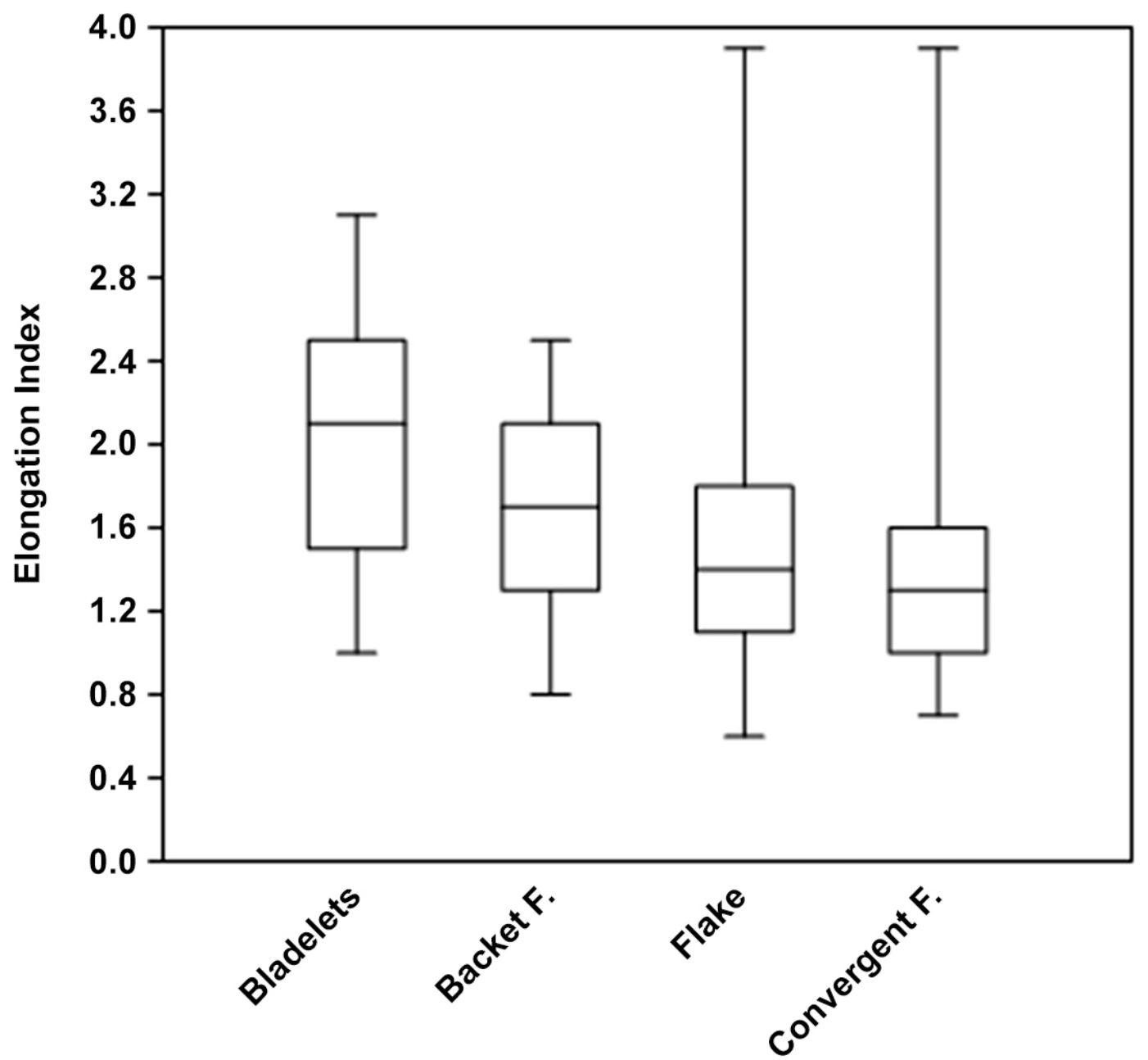

Figure 6: Elongation Index target flakes. Bladelets $(N=26)$, backed flakes $(N=37)$, flakes $(N=200)$ and convergent flakes $(\mathrm{N}=88)$.

\subsection{RMU: Import, export}

Despite the limitations posed by the incompleteness of the excavated area and by the fact that not all the materials are comprised in the RMU (5197 pieces of first and second DC are excluded), we were able to identify a great number of RMU: 279 RMU made up of 1770 pieces, and of this group 128 formed 53 refitting or conjoint sets. Each RMU is made up of 
many or few pieces and they also show variations in their technological composition. A great number of RMUs consist of one or a few pieces (max 5 items), whereas there are few RMUs with many items (Table 6).

Table 6: Quantity of pieces in each RMU, and amount of pieces and RMU for each raw material.

\begin{tabular}{|c|c|c|c|c|c|c|c|}
\hline $\begin{array}{l}\text { Quantity of } \\
\text { pieces in each } \\
\text { RMU }\end{array}$ & $\begin{array}{l}\text { Fine and } \\
\text { medium } \\
\text { jasper }\end{array}$ & $\begin{array}{l}\text { Fine } \\
\text { chert }\end{array}$ & Limestone & $\begin{array}{c}\text { Medium } \\
\text { chert }\end{array}$ & $\begin{array}{c}\text { Quartz } \\
\text { sandstone }\end{array}$ & $\begin{array}{l}\text { Siliceous } \\
\text { limestone }\end{array}$ & $\begin{array}{l}\text { Total } \\
\text { RMU }\end{array}$ \\
\hline pieces & 679 & 98 & 16 & 263 & 144 & 570 & \\
\hline 1 & 30 & 2 & 6 & 14 & & 48 & 100 \\
\hline 2 to 5 & 31 & 7 & 1 & 20 & 1 & 39 & 99 \\
\hline 6 to 20 & 21 & 2 & 1 & 13 & 1 & 23 & 61 \\
\hline 21 to 40 & 8 & & & 1 & 2 & & 11 \\
\hline 41 to 60 & 2 & 1 & & 1 & & 2 & 6 \\
\hline$>60$ & & & & & 1 & 1 & 2 \\
\hline Total RMU & 92 & 12 & 8 & 49 & 5 & 113 & 279 \\
\hline
\end{tabular}

From a technological point of view the target or the retouched objects are part of the RMUs consisting of just one piece or few pieces. That means that all the reduction sequences of these pieces might have occurred outside the rock shelter, consequently these pieces could have been introduced into the site as already finished objects, thus they could be considered imported items. Some of the cores (most of them almost depleted) also belong to this first group of RMUs with few pieces. The absence of the target product belonging to these cores make us hypothesise that the finished tools were exported from the site. The few RMUs, where all the phases of the reduction sequences are simultaneously represented, give us the evidence to support the idea that some RMUs were introduced into the site as raw pebbles, which were then knapped completely at the site (Spagnolo et al.2016).

On a close examination, considering the number of pieces in each RMU and their technological composition (i.e. which type and how many pieces relate to the different phases of the reduction sequence: acquisition $=$ pebbles; management $=$ management flakes and micro-flakes; production = target flakes; abandonment $=$ completely exploited cores) it is possible to gain a higher and more detailed definition (Table 7).

The importation of materials from outside to inside the rock shelter (Import) is documented by the presence of imported pebbles (7 RMUs) and target flakes (47 RMUs). It is also possible to envisage the import of semi-worked objects based on 47 RMUs, which include all stages of the reduction sequence excluding the cortex removal, which necessarily occurred elsewhere (Table 7).

The transport of objects from the site to the outside (Export) is attested by the RMUs with incomplete reduction sequences. The presence of 40 RMUs made up only of completelycortical and semi-cortical flakes, leads us to suppose that the first phase of pebbles opening and decortication took place at the site. Later these pebbles were exported from the site as semi-worked pieces ( $1^{\circ}$ stage). Two RMUs, composed only of management pieces, indicate the export of semi-finished items related to a more advanced stage of the reduction $\left(2^{\circ}\right.$ stage). Moreover the presence of 24 RMUs composed of numerous elements of cortex removal and management but lacking target objects suggests the export of these finished tools.

Furthermore there are 9 RMUs in which all stages of the reduction sequence are attested in situ and 49 RMUs where all phases of the reduction sequence except for cores are represented. The cores usually can be reused, removed from the site or treated as waste. In both the former cases it is assumed that the above 58 RMUs were introduced in level US 13 
as pebbles and entirely knapped inside the rock shelter from the first stages of debitage until abandonment.

Table 7: Technological composition of RMU, their explanation in terms of human behaviour and number of RMU that support this evidence.

$\begin{array}{llc}\text { RMU composition } & \text { Behavioral explanation } & \text { N. of RMU } \\ \text { Pebble } & \text { Acquisition } & 7 \\ \text { Target flake and core } & \text { Import-Finished tool } & 4 \\ \text { Target flake } & \text { Import-Finished tool } & 34 \\ \text { Decortex and target flake } & \text { Import-Finished tool } & 8 \\ \text { Decortex, target flake and core } & \text { Import-Finished tool } & 1 \\ \text { Outside decortex, inside production } & \text { Import-Semi worked items } & 47 \\ \text { Decortex and management in situ } & \text { Export-Finished tool } & 23 \\ \text { Management and core } & \text { Export-Semi worked items } & 2 \\ \text { Decortex, management and core in situ } & \text { Export-Finished tool } & 1 \\ \text { Just inside decortex } & \text { Export-Semi worked items } & 40 \\ \text { Complete reduction sequence without core } & \text { In situ production } & 49 \\ \text { Complete reduction sequence } & \text { In situ production } & 9 \\ \text { Only complete exploited core } & \text { Waste } & 9 \\ \text { Just inside management } & \text { Indeterminable } & 45 \\ \text { Total } & & \mathbf{2 7 9}\end{array}$

Nine RMUs are made only by completely exploited cores indicating the abandonment and waste of debitage. Finally for 45 RMUs (made up of management flakes) it was not possible to envisage a behavioural interpretation.

\section{Discussion and conclusions}

To sum up, the technical behaviour of Neanderthals at level 13 of Oscurusciuto shows a great degree of fragmentation of the reduction sequences. The record is made up of several instances of introduction of lithic material at different stages of manufacturing. Pieces were introduced in the form of rough objects (pebbles), as well as semi-finished items, and as finished tools.

As a result of technological analysis and the study of the RMUs we are able to propose a scenario of how the Neanderthal production of lithic material occurred at the Oscurusciuto level 13. Once pebbles had been imported, there is a unipolar Levallois process of cortex removal and a first-generation of unipolar flakes, then followed a phase of corerestructuration in order to get a second generation of unipolar supports, or a restructuration in a convergent Levallois process, concluded by a convergent production. However, convergent Levallois cores may also have been introduced to the site as semi-worked pieces. The same scenario is valid for the volumetric cores which, made from flakes or fragments, may have been imported into the site as semi-worked items, or which may simply have been broken fragments resulting from in situ knapping. Furthermore, tools have been imported into the site as finished objects while, in return, some finished objects have been exported from the site. At some point, also some tested pebbles and semi-manufactured pieces were exported from the site (Figure 7).

The fragmentation of the chaîne opératoire in several instances of import or export demonstrate the palimpsest nature of the level which is made up of different events happening one after another. This also indicates a certain mobility of the population in this territory. In 
other words, there would then necessarily be other sites where the complementary phases of the reduction sequences have taken place, or where the respective target products were utilized and abandoned.

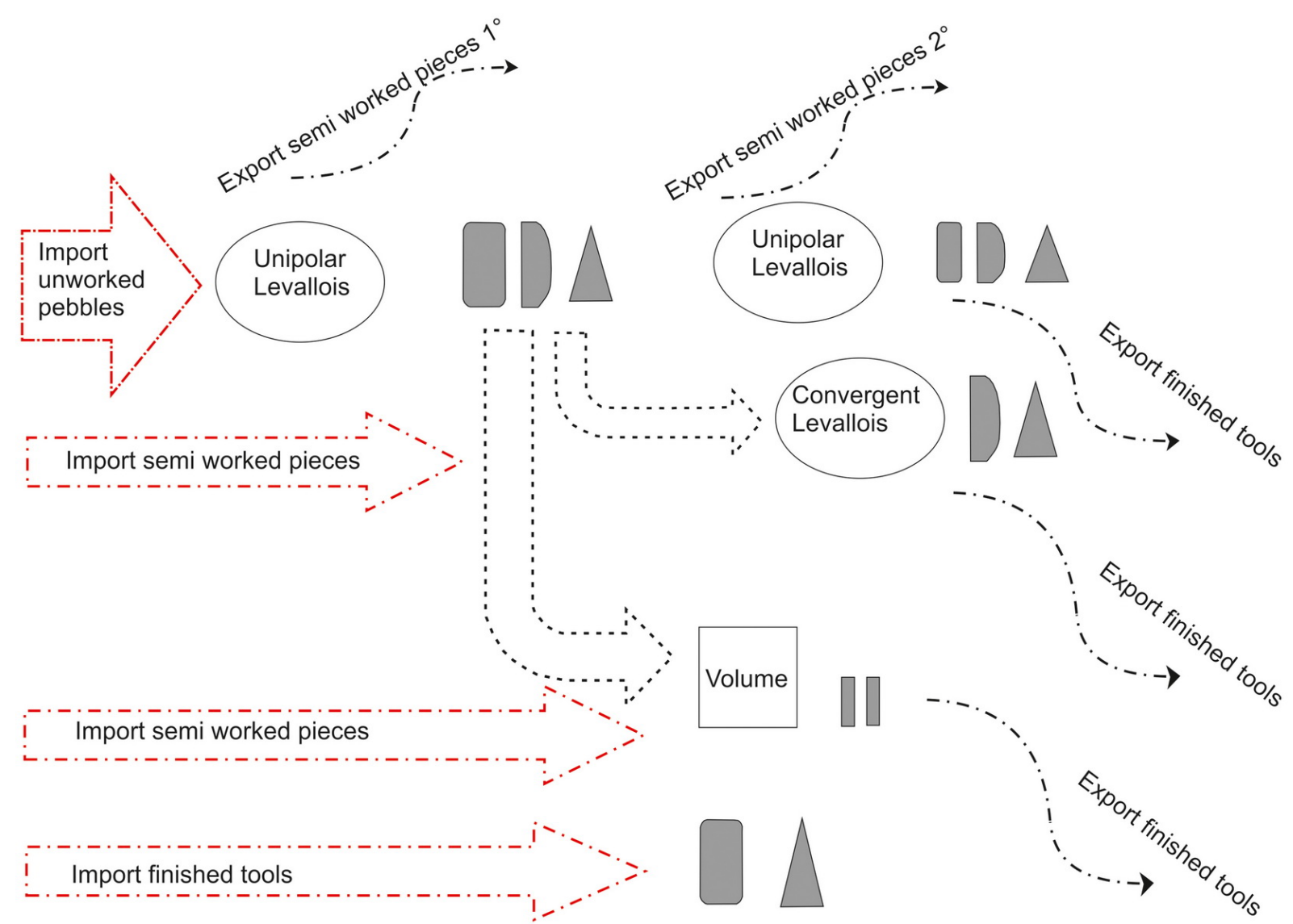

Figure 7. Fragmented reduction sequences. The grey silhouettes represent the target flakes (big rectangle = flakes; triangle = convergent flakes; half oval = backed flakes; small rectangle = bladelets).

Not far from Oscurusciuto in the peninsula of Salento, more precisely in the layer L of Grotta del Cavallo (at the end of MIS, 5 beginning of MIS 4), a high degree of mobility in the territory is attested for Neanderthal populations on the basis of a different archaeological record. Together with the fragmentation of the reduction sequences, it also demonstrates the recycling of lithic tools. This evidence is proved by the presence of pieces with double patinas, exogenous raw materials and objects characterized by a large investment in retouching. This behaviour is interpreted as an occasional practice performed in response to unplanned needs (Romagnoli 2012; 2015).

Having reached some conclusions, new questions and problems arise. We have noted that the target flakes could be both the main objects in actions of import and export, as well as the ultimate goal of the whole process of debitage. But what exactly was their role in the society where they were produced? Since they represented a great technical investment, were they objects meant to have a comparatively long life? In order that these questions are adequately answered it is necessary to perform techno-functional and use wear analysis. Afterwards, these data will be analysed in the GIS platform to gain specific information on the functionality of the spaces.

The results obtained with the study of RMUs invite us to continue in this direction. In fact, we decided to carry out a specific experimental protocol with the aim to further verify the interpretation given on the basis of the study of the RMUs. 


\section{Acknowledgements}

The authors are indebted to the Soprintendenza Archeologia della Puglia, Municipality of Ginosa, Onlus CESQ, to Piero di Canio and to all the students and colleagues (Claudia Abruzzese, Francesco Boschin, Silvana Condemi, Jacopo Crezzini, Elena D'Itria, Stefania Mainieri, Giulia Musella, María José Peñalver Puerta, Marco Serradimigni) who participated, together with the authors, in the excavation of 2011. We would like to warmly acknowledge Brigitte Hoiberg Nilsen and Sharada Channarayapatna for proofreading this article. This paper was presented at 10th International Symposium on Knappable Materials On the rocks held in University of Barcelona between 7 and 15 September 2015. We would like to acknowledge Marta Arzarello, Claire Gaillard, Luca Foresi, Marcos César Pereira Santos, Sem Scaramucci, Antoine Lourdeau, Lucia Dallafior the session organizers Killian Driscoll and Didac Roman and the two anonymous reefers that provide precious advice to enrich this paper.

\section{References}

Allen, J.R.M., Watts, W.A., \& Huntley, B. 2000, Weichselian palynostratigraphy, palaeovegetation and palaeoenvironments; the record from Lago Grande di Monticchio, southern Italy. Quaternary International, 73: 91-110. doi:10.1016/S10406182(00)00067-7

Amick, D.S. 2007, Behavioral causes and archaeological effects of lithic artifact recycling. In: Tools versus Cores: Alternative Approches to Stone Tool Analysis (McPherron, S., Ed.), Cambridge Scholars Publications, Newcastle: p. 223-252.

Bataille, G. 2006, Kabazi II, Level II/8: Import and Evacuation of Lithic Material. Kabazi II: The 70000 years since the Last Interglacial. The Palaeolithic Sites of Crimea (Chabai, V. P., Richter J. \& Uthmeier T., Eds.), Simferopol, Colonia: p. 131-142.

Boëda, E. 1982, Etude expérimentale de la technologie des pointes Levallois in Tailler! Pourquoi faire: Préhistoire et technologie lithique II, Recent Progress in Microwear Studies. Studia Praehistorica Belgica Leuven, 2: 23-56. (in French) (Experimental study of Levallois point technology during Knapping! Why to do it: Prehistory and lithic technology II)

Boëda, E. 1993, Le débitage discoïde et le débitage Levallois récurrent centripète. Bulletin de la Société Préhistorique Française, 90(6): 392-404. doi:10.3406/bspf.1993.9669. (in French) (Discoid debitage and Levallois recurrent centripetal debitage)

Boëda, E. 1994, Le concept Levallois: Variabilité des méthodes, Monographie du Centre de Recherches Archéologiques (CRA) Vol. 9, Centre national de la recherche scientifique (CNRS) Éditions, Paris, 280 P. (in French) (The concept Levallois: methods variability)

Boëda, E. 2013, Techno-logique \& technologie: Une paléo-histoire des objets lithiques tranchants. @9Chéo-éditions.com (publisher), Prigonrieux, 266 p. (in French) (Technologic and technology: Palaeohistory of sharp lithic objects)

Boscato, P., Gambassini, P., Ranaldo, F., \& Ronchitelli, A. 2011, Management of Paleoenvironmental Resources and Exploitation of Raw Materials at the Middle Paleolithic Site of Oscurusciuto (Ginosa, Southern Italy): Units 1 and 4. In: Neanderthal Lifeways, Subsistence and Technology (Conard, N. J. \& Richter, J., Eds.), Springer, New York: p. 87-96. 
Boscato, P., \& Crezzini, J. 2012, Il deposito musteriano del Riparo l’Oscurusciuto (Ginosa TA): La fauna a grandi mammiferi delle UUSS $1 \div 9$. In: Atti $6^{\circ}$ Convegno Nazionale di Archeozoologia. Associazione Italiana di Archeozoologia, (De Grossi Mazzorin, J., Saccà, D., \& Tozzi, C., Eds.), Associazione Italiana ArcheoZoologia AIAZ, Lecce: p. 25-32. (in Italian) (The Mousterian deposit of the Oscurusciuto rock shelter (Ginosa TA): Large mammals faunal remains of UUSS 1 to 9)

Boscato, P., \& Ronchitelli, A. 2008, Strutture di combustione in depositi del Paleolitico medio del Sud Italia. In: Atti XVII Congresso dell'Associazione Antropologica Italiana (Mannino, M., Di Salvo, R., Schimmenti, V., Messina, A. \& Sineo, L., Eds.), International Journal of Anthropology, Vol. Supplement, Springer, New York: p. 218225. (in Italian) (Combustion structures in Middle Paleolithic deposit in South Italy)

Bourguignon, L., Faivre, J. P., \& Turq, A. 2004, Ramification des chaînes opératoires: Une spécificité du Moustérien. Paléo, 16: 37-48. (in French) (Reduction sequences ramification: A Mousterian specificity)

Bruce, K. L. 2001, All Rocks are Not Alike. Southeastern Archaeology, 20(1): 78-92.

Buonsanto, C. 2012, Individuazione degli errori di scheggiatura nei diversi metodi di débitage del Paleolitico inferiore e medio. Gli esempi di Cà Belvedere di Monte Poggiolo (FC), Guado San Nicola 1 (IS), Riparo Tagliente (VR), Payre e Abri du Maras (Ardéche, Francia). Ph.D. Thesis, Università degli Studi di Ferrara, Ferrara, 346 p. (in Italian) (Identification of knapping errors in several lower and middle Palaeolithic methods of débitage. Examples of Cà Belvedere Monte Poggiolo (FC), Guado San Nicola (IS), Riparo Tagliente (VR), Payre and Abri du Maras (Ardeche, France))

Buonsanto, C., \& Peretto, C. 2012, The Flintknapping errors at the service of learning. Journal of Biological Research-Bollettino della Società Italiana di Biologia Sperimentale, 85(1): 76-79.

Byrnes, A. 2009, Frederick component at Locality I. In: Hell Gap: A stratified Paleoindian Campsite at the edge of the Rockies (Larson, M.L., Kornfeld, M., \& Frison. G., Eds.), University of Utah Press, Salt Lake City: p. 216-228.

Carmignani, L. 2010, L'industria litica del livello F IIIE di Grotta del Cavallo (Nardò, Lecce). Osservazioni su una produzione lamino e lamellare in un contesto del Musteriano Finale. In: Origini XXXII, Preistoria e protostoria delle civiltà antiche (Manfredini, A., Ed.), Gangemi Spa, Rome: p. 7-26. (in Italian) (The lithic assemblages of the level F IIIE of Grotta del Cavallo (Nardò, Lecce). Observations on blades and bladelets production in a Final Musterian context)

Carmignani, L. 2011, Le ultime espressioni del Musteriano nell'Italia del sud-est. Variabilità tecnologiche e comportamenti tecno-economici in un contesto peninsulare. I casi studio di Grotta del Cavallo e Grotta Mario Bernardini. Nardò (Lecce). Ph.D. Thesis, Università degli Studi di Siena, Siena, \& Paris X, Paris, 257 p. (in Italian) (The latest expression of the Mousterian in southern-east Italy. Technological variability and techno-economic behavior in a peninsular context. The case studies of Grotta del Cavallo and Grotta Mario Bernardini. Nardò, Lecce)

Chacón, M. G., Bargalló, A., Gabucio, M. J., Rivals, F., \& Vaquero, M. 2015, Neanderthal behaviors from a spatio-temporal perspective: An interdisciplinary approach to interpret archaeological assemblages. In: Settlement Dynamics of the Middle Paleolithic and Middle Stone Age IV (Conard, N. J., \& Delagnes, A., Eds.), Publications in Prehistory, Tübingen: p. 253-294. 
Cooper, J. R., \& Meltzer, D. J. 2009, Investigations at 5gn149, a lithic workshop in the Upper Gunnison Basin, Colorado. Southwestern Lore, 75(1-2): 3-29.

Close, A.E. 1996, Carry that weight: The use and the transportation of stone tools. Current Anthropology 37: 545-553. doi:10.1086/204517

Cziesla, E. 1990, On refitting of stone artefacts. In: The Big Puzzle: International Symposium on Refitting Stone Artefacts (Cziesla, E., Ed.), Studies in Modern Archaeology Vol 1, Holos, Bonn: p. 9-44.

Dibble, H.L., \& Rolland, N. 1992, On assemblage variability in the Middle Paleolithic of Western Europe. History, perspectives and a new synthesis. In: The Middle Paleolithic: Adaptation, Behaviour and Variability (Dibble, H.L., \& Mellars, P., Eds.), The University Museum, University of Pennsylvania, Philadelphia: p. 1-28.

Douglass, M. J. 2010, The archaeological potential of informal lithic technologies: A case study of assemblage variability in Western New South Wales, Australia. Ph.D. Thesis at the University of Auckland, Auckland, 332 p.

Fernández-Laso, M. C., Navarro, M. G. C., García-Antón, M. D., \& Rivals, F. 2011, Territorial mobility of Neanderthal groups: A case study from Level M of Abric Romaní (Capellades, Barcelona, Spain). In: Neanderthal lifeways, subsistence and technology (Conard, N. J., \& Richter, J., Eds.), Springer, Netherlands: p. 187-202.

Forestier, H. 1993, Le Clactonien: Mise en application d'une nouvelle méthode de débitage s'inscrivant dans la variabilité des systèmes de production lithique du Paléolithique ancient. Paléo, 5: 53-82. (in French) (The Clactonian: Implementation of a new method of debitage enrolling in the variability of lithic production systems of the ancient Palaeolithic) doi:10.3406/pal.1993.1104

Geneste, J. M. 1991, Systèmes techniques de production lithique: Variations technoéconomiques dans les processus de réalisation des outillages paléolithiques. Techniques \& culture, 17-18: 1-35. (in French) (Lithic production technical systems: Technoeconomic changes in the process of realization of Palaeolithic tools)

Hall, C. T. 2004, Evaluating prehistoric hunter-gatherer mobility, land use, and technological organization strategies. In: Aggregate analysis in chipped stone (Hall, Ch. T., \& Larson, M. L., Eds.), University of Utah Press, Salt Lake City: p. 139-155.

Hall, C. T., \& Larson, M. L. 2004, Aggregate analysis in chipped stone. University of Utah Press, Salt Lake City, 272 p.

Hallos, J. 2005, “15 Minutes of Fame”: Exploring the temporal dimension of Middle Pleistocene lithic technology. Journal of Human Evolution, 49(2): 155-179. doi:10.1016/j.jhevol.2005.03.002

Hiscock, P. 2009, Reduction, recycling, and raw material procurement in Western Arnhem Land, Australia. In: Lithic Materials and Paleolithic Societies (Adams, B., \& Blades, B. S., Eds.), Wiley- Blackwell Publishing, Oxford: p. 78-93. doi:10.1002/9781444311976.ch6

Hurst, S., Johnson, E., Holliday, V. T., \& Butler, S. 2010, Playa Archaeology on the Southern High Plains of Texas: A Spatial Analysis of Hunter-Gatherer Occupations at TahokaWalker (41L Y53). Plains Anthropologist, 55(215): 195-214. doi:10.1179/pan.2010.018 
Inizan, M. L., Reduron-Ballinger, M., Roche H., \& Tixier, J. 1999, Technology and terminology of knapped stone. Centre de Recherches et d'Études Préhistoriques Editions, Meudon, 191 p.

Kelly, R. L. 1988, The three sides of a biface. American Antiquity 53: 717-734. doi:10.2307/281115

Knell, E. J. 2012, Minimum Analytical Nodules and Late Paleoindian Cody Complex Lithic Technological Organization at Hell Gap, Wyoming. Plains Anthropologist, 57(224): 325-351. doi:10.1179/pan.2012.024

Kuhn, S. L. 2014, Mousterian Lithic Technology: An Ecological Perspective. Princeton University Press, Princeton, 224 p. URL: http://www.jstor.org/stable/j.ctt7zv59w

Larson, M. L. 1994, Toward a holistic analysis of chipped stone assemblages. In: The organization of North American prehistoric chipped stone tool technologies (Carr, P. J., Ed.), Archaeological series Vol. 7, International Monographs in Prehistory, Ann Arbor, Michigan: p. 57-69.

Larson, M. L., \& Ingbar, E. E. 1992, Perspectives on refitting: Critique and supplementary approach. In: Piecing together the past: Applications of refitting studies in archaeology, (Hofman, J. L., \& Enloe, J. G., Eds.), BAR International Series Vol. 578, Tempus Reparatum, Oxford, p. 151-161.

Larson, M. L., \& Kornfeld, M. 1997, Chipped stone nodules: Theory, method, and examples. Lithic Technology, 22(1): 4-18. doi:10.1080/01977261.1997.11754530

Larson, M. L., \& Finley, J. B. 2004, Seeing the trees but missing the forest: Production sequences and multiple linear regression. In: Aggregate analysis in chipped stone (Hall, C. T., \& Larson, M. L., Eds.), University of Utah Press, Salt Lake City: p. 95-111.

Lazzeri, C. 2005, Il Riparo dell'Oscurusciuto alla gravina di Ginosa (TA). Applicazione di funzioni CAD allo studio del materiale litico dell'US 4/1. BA Thesis at the Università di Siena, Siena, 33 p. (in Italian) (The Oscurusciuto rock shelter at the ravine of Ginosa (TA). Application of CAD functions to the study of the lithic material of the US 4/1)

Leroi Gourhan, A. 1943, Évolution et techniques I: L'homme et la matière. Michel A., Ed., Paris, 352 p. (in French) (Evolution and technics I: Man and material)

López-Ortega, E., Rodríguez, X. P., \& Vaquero, M. 2011, Lithic refitting and movement connections: The NW area of level TD10-1 at the Gran Dolina site (Sierra de Atapuerca, Burgos, Spain). Journal of Archaeological Science, 38(11): 3112-3121. doi:10.1016/j.jas.2011.07.011

López-Ortega, E., Bargalló, A., de Lombera-Hermida, A., Mosquera, M., Ollé, A., \& Rodríguez-Álvarez, X. P. 2015, Quartz and quartzite refits at Gran Dolina (Sierra de Atapuerca, Burgos): Connecting lithic artefacts in the Middle Pleistocene unit of TD10. 1. Quaternary International (2015): 1-18. doi:10.1016/j.quaint.2015.09.026

Machado, J., Hernández, C. M., \& Galván, B. 2011, Contribución teórico-metodológica al análisis histórico de palimpsestos arqueológicos a partir de la producción lítica. Un ejemplo de aplicación para el Paleolítico medio en el yacimiento de El Salt (Alcoy, Alicante). Recerques del Museu D'Alcoi, 20: 33-46. (in Spanish) (Theoretical and methodological contributions of historical analysis of archaeological palimpsests starting from lithic production. An application example for the Middle Palaeolithic at the site of El Salt Alcoy, Alicante) 
Machado, J., Hernández, C. M., Mallol, C., \& Galván, B. 2013, Lithic production, site formation and Middle Palaeolithic palimpsest analysis: In search of human occupation episodes at Abric del Pastor Stratigraphic Unit IV (Alicante, Spain). Journal of Archaeological Science, 40: 2254-2273. doi:10.1016/j.jas.2013.01.002

Machado, J., Mallol, C., \& Hernández, C. M. 2015, Insights into Eurasian Middle Palaeolithic settlement dynamics: The palimpsest problem. In: Settlement Dynamics of the Middle Paleolithic and Middle Stone Age IV (Conard, N. J., \& Delagnes, A., Eds.), Publications in Prehistory, Tübingen: p. 361-382.

Marciani, G. 2013, The Lithic Assemblage of the US 13 at the Middle Paleolithic Site of Oscurusciuto (Ginosa, Taranto, Southern Italy): Technological Studies. MA Thesis Erasmus Mundus at the Instituto Politecnico de Tomar, Tomar and at the Universidade de Tras-os-Montes e Alto Douro, Vila Real, 163 p.

URI: http://hdl.handle.net/10400.26/6019

Miller, G. L. 2016, MANA from heaven: Testing the utility of minimum analytical nodule analysis at large, repeatedly reoccupied ceremonial sites. Journal of Archaeological Science: Reports, 8: 1-10. doi:10.1016/j.jasrep.2016.05.053

Moncel, M. H., Chacón, M. G., La Porta, A., Fernandes, P., Hardy, B., \& Gallotti, R. 2014, Fragmented reduction processes: Middle Palaeolithic technical behaviour in the Abri du Maras shelter, southeastern France. Quaternary International, 350: 180-204. doi:10.1016/j.quaint.2014.05.013

Moroni, A., Boscato, P., \& Ronchitelli, A. 2013. What roots for the Uluzzian? Modern behaviour in Central-Southern Italy and hypotheses on AMH dispersal routes. Quaternary International, 316: 27-44. doi:10.1016/j.quaint.2012.10.051

Neruda, P. 2010, Economic behavior and mental capacity of Neanderthals. In: Ecce Homo. In memoriam Jan Fridrich (Fridrichová-Sýkorová, I., Ed.), Series Knižnice České společnosti archeologické, Krigl, Prague, p. 111-129.

Neruda, P. 2012, Impact of raw materials on the interpretation of Middle Palaeolithic assemblages. Anthropologie, 50(3): 345-360.

Ramsey, C. B., \& Lee, S. 2013, Recent and Planned Developments of the Program OxCal. Radiocarbon, 55(2-3): 720-730. doi:10.2458/azu_js_rc.55.16215

Ranaldo, F. 2005, Il Musteriano del Riparo L'Oscurusciuto nella gravina di Ginosa (TA): Studio tecnico e tipologico dell'industria litica dell'US 1. MA Thesis at the Università di Padova, Padova, 171 p. (in Italian) (The Mousterian of the Oscurusciuto rock shelter in the ravine of Ginosa (TA): Technical and typological study of the lithic industry of the US 1)

Revillion, S., \& Tuffreau, A. 1994, Les industries laminaires au Paléolithique moyen. Actes de la table ronde internationale de Villeneuve-d'Ascq (13-14 novembre 1991). Dossiers de Documentation Archéologique Vol. 18, CNRS Éditions, Paris, 191 p. (in French) (Laminar industries in the Middle Paleolithic)

Rios-Garaizar, J., Maidagan, D. G., Gómez-Olivencia, A., Iriarte, E., Arceredillo-Alonso, D., Iriarte-Chiapusso, M. J., Garcia-Ibaibarriaga, N., García-Moreno, A., Gutierrez-Zugasti, I., Torres, T., Aranburu, A., Arriolabengoa, M., Bailón, S., Murelaga, X., Ordiales, A., Ortiz, J. E., Rofes, J., \& San Pedro, Z. 2015, Short-term Neandertal occupations in the late Middle Pleistocene of Arlanpe (Lemoa, northern Iberian Peninsula). Comptes Rendus Palevol, 14(3): 233-244. doi:10.1016/j.crpv.2014.11.006 
Roebroeks, W. 1988, From find scatters to early hominid behavior: A study of middle palaeolithic riverside settlements at Maastricht-Belvédère (The Netherlands). Ph.D. Thesis at the University of Leiden, Leiden, 198 p.

Romagnoli, F. 2012, Risorse litiche e comportamento tecnico dei Neandertaliani: Variabilità culturale e adattamento all'ambiente nel Salento. Grotta del Cavallo, Strati L-N e Grotta Mario Bernardini, Strato D. Ph.D. Thesis Erasmus at the Università di Firenze, Florence and at the Universitat Rovira i Virgili, Tarragona, 405 p. (in Italian) (Lithic resources and technical behavior of Neanderthals: Cultural variability and adaptation to the environment in Salento. Grotta del Cavallo, layers L-N and Grotta Mario Bernardini, Layer D)

Romagnoli, F. 2015, A second life: Recycling production waste during the Middle Palaeolithic in layer L at Grotta del Cavallo (Lecce, Southeast Italy). Quaternary International, 361: 200-211. doi:10.1016/j.quaint.2014.07.033

Romagnoli, F., Baena J., \& Sarti L. 2015, Neanderthal retouched shell tools and Quina economic and technical strategies: An integrated behaviour. Quaternary International, 407: 29-44. doi:10.1016/j.quaint.2015.07.034

Ronchitelli, A., Freguglia, M., Longo, L., Moroni Lanfredini, A., \& Ranaldo, F. 2011, Studio tecno-funzionale dei supporti a morfologia triangolare dell’US 8 del Riparo l’Oscurusciuto (Ginosa - Taranto). Rivista di Scienze Preistoriche, 61: 5-20. (in Italian) (Techno-functional study of the triangular tools of the US 8 of the Oscurusciuto rockshelter Ginosa - Taranto)

Scerri, E. M., Gravina, B., Blinkhorn, J., \& Delagnes, A. 2016, Can lithic attribute analyses identify discrete reduction trajectories? A quantitative study using refitted lithic sets. Journal of Archaeological Method and Theory, Vol. 23(2): 669-691. doi:10.1007/s10816-015-9255-x

Schurmans, U. 2007, Refitting in the Old and New World. In: Fitting rocks: Lithic refitting examined (Schurmans, U., \& De Bie, M., Eds.), BAR International Series Vol. 1596, Archaeopress, Oxford: p. 7-23.

Spagnolo, V. 2013, Analisi spaziale di un contesto musteriano: Riparo L'Oscurusciuto (Ginosa - TA). MA Thesis at the Università del Salento, Lecce, 210 p. (in Italian) (Spatial analysis of a Mousterian contex: The Oscurusciuto rock shelter (Ginosa - TA))

Spagnolo, V., Marciani, G., Aureli, D., Berna, F., Boscato, P., Ranaldo, F., Ronchitelli, A. 2016, Between hearths and volcanic ash: The SU 13 palimpsest of the Oscurusciuto rock shelter (Ginosa - Southern Italy): Analytical and interpretative questions. Quaternary International, 417: 105-121. doi:10.1016/j.quaint.2015.11.046

Spinapolice, E. 2012, Raw material economy in Salento (Apulia, Italy): New perspectives on Neanderthal mobility patterns. Journal of Archaeological Science, 39(3): 680-689. doi:10.1016/j.jas.2011.10.033

Turq, A., Roebroeks, W., Bourguignon, L., \& Faivre, J. P. 2013, The fragmented character of Middle Palaeolithic stone tool technology. Journal of Human Evolution, 65(5): 641655. doi:10.1016/j.jhevol.2013.07.014

Uthmeier, T. 2006, Stone Tools, Horses and Cognition: Transformation of Lithic Raw Materials at the Middle Paleolithic Open Air Kill and Butchering Site of Kabazi II, Level III/1. In: Kabazi II: The 70000 Years Since the Last Interglacial (Jürgen Richter, V. C., \& Uthmeier, T., Eds.), Simferopol, Colonia: p. 253-269. 
Vallverdù, J., Allué, E., Bischoff, J. L., Cáceres, I., Carbonell, E., Cebrià, A., Garcìa-Antón, D., Huguet, R., Ibáñez, N., Martìnez, K., Pasto I., Rosell, J., Saladié, P., \& Vaquero, M. 2005, Short human occupations in the Middle Palaeolithic level i of the Abric Romaní rock-shelter (Capellades, Barcelona, Spain). Journal of Human Evolution, 48: 157-174. doi:10.1016/j.jhevol.2004.10.004

Vallverdù, J., Vaquero, M., Cáceres, I., Allué, E., Rosell, J., Saladié, P., Chacón, G., Ollé, A., Canals, A., Sala, R., Courty, M. A., \& Carbonell, E. 2010, Sleeping Activity Area within the Site Structure of Archaic Human Groups: Evidence from Abric Romaní Level N Combustion Activity Areas. Current Anthropology, 51(1): 137-145. doi:10.1086/649499

Vaquero, M., Vallverdù, J., Rosell, J., Pasto, I., \& Allue, E. 2001, Neanderthal Behavior at the Middle Palaeolithic Site of Abric Romani, Capellades, Spain. Journal of Field Archaeology, 28: 93-114. doi:10.1179/jfa.2001.28.1-2.93

Vaquero, M. 2008, The history of stones: behavioural inferences and temporal resolution of an archaeological assemblage from the Middle Palaeolithic. Journal of Archaeological Science, 35: 3178-3185. doi:10.1016/j.jas.2008.07.006

Vaquero, M. 2011, New prespectives on recycling of lithic resources using refitting and spatial data. Quartär, 58: 113-130.

Vaquero, M., Alonso, S., García-Catalán, S., García-Hernández, A., Gómez de Soler, B., Retting, D., \& Soto, M. 2012, Temporal nature and recycling of Upper Paleolithic artifacts: The burned tools from the Molí del Salt site (Vimbodí I Poblet northeastern Spain). Journal of Archaeological Science, 39: 2785-2796.

doi:10.1016/j.jas.2012.04.024

Vaquero, M., Chacòn, M. G., Cuartero, F., Garcia-Anton, M. D., Gòmez De Soler, B., \& Martinez, K. 2012a, The Lithic Assemblage of Level J. In: High Resolution Archaeology and Neanderthal Behavior. Time and Space in Level J of Abric Romaní (Capellades, Spain) (Carbonell I Roura, E., Ed.), Springer, Dordrecht: p. 189-311.

Vaquero, M., Chacón, M. G., Cuartero, F., García-Antón, M. D., Gómez de Soler, B., \& Martínez, K. 2012b, Time and space in the formation of lithic assemblages: The example of Abric Romaní Level J. Quaternary International, 247: 162-181. doi:10.1016/j.quaint.2010.12.015

Vaquero, M., Bargalló, A., Chacón, M. G., Romagnoli, F., \& Sañudo, P. 2015, Lithic recycling in a Middle Paleolithic expedient context: Evidence from the Abric Romaní (Capellades, Spain). Quaternary International, 361: 212-228.

doi:10.1016/j.quaint.2014.05.055

Villa, P., Boscato, P., Ranaldo, F., \& Ronchitelli, A. 2009, Stone tools for the hunt: Points with impact scars from a Middle Paleolithic site in southern Italy. Journal of Archaeological Science, 36: 850-859. doi:10.1016/j.jas.2008.11.012

White, B. 2012, Minimum analytical nodules and lithic activities at site W2, Hunter Valley, New South Wales. Australian Archaeology, 75: 25-36. doi:10.1080/03122417.2012.11681947

Yoshikawa, K. 2010, The Palaeolithic exploitation of the lithic raw materials and the organization of foraging territory in Northeastern Japan. Asian Perspectives, 49(2): 294317. doi:10.1353/asi.2010.0016 